Article

\title{
Classifying Pathways for Smart City Development: Comparing Design, Governance and Implementation in Amsterdam, Barcelona, Dubai, and Abu Dhabi
}

\author{
Negar Noori ${ }^{1}$, Thomas Hoppe ${ }^{2, *} *$ and Martin de Jong ${ }^{1,3}$ \\ 1 Erasmus School of Law and Rotterdam School of Management, Erasmus University Rotterdam, Rotterdam, \\ 3000 DR Rotterdam, The Netherlands; noori@law.eur.nl (N.N.); w.m.jong@law.eur.nl (M.d.J.) \\ 2 Faculty of Technology, Policy and Management (TPM), Delft University of Technology, \\ 2628 BX Delft, The Netherlands \\ 3 Institute for Global Public Policy, Fudan University, Shanghai 200433, China \\ * Correspondence: T.Hoppe@tudelft.nl
}

Received: 28 March 2020; Accepted: 12 May 2020; Published: 14 May 2020

\begin{abstract}
The emergence of the Internet of Things (IoT) as the new paradigm of Information and Communication Technology (ICT) and rapid changes in technology and urban needs urge cities around the world towards formulating smart city policies. Nevertheless, policy makers, city planners, and practitioners appear to have quite different expectations from what smart cities can offer them. This has led to the emergence of different types of smart cities and pathways of development. This paper aims to answer the research question: When comparing a selection of smart city projects, can we classify pathways for their implementation? We do this by using a cross-case research design of four cities to explore commonalities and differences in development patterns. An input-output (IO) model of smart city development is used to retrieve which design variables are at play and lead to which output. The four cases pertain to the following smart city projects: Smart Dubai, Masdar City, Barcelona Smart City, and Amsterdam Smart City. Our analysis shows that Amsterdam is based on a business-driven approach that puts innovation at its core; for Masdar, technological optimism is the main essence of the pathway; social inclusion is the focus of Barcelona Smart City; and visionary ambitious leadership is the main driver for Smart Dubai. Based on these insights, a classification for smart city development pathways is established. The results of the present study are useful to academic researchers, smart city practitioners, and policy makers.
\end{abstract}

Keywords: smart city; input-output model; design variables; comparative analysis; smart governance; digitization; Smart Dubai; Masdar City; Barcelona Smart City; Amsterdam Smart City

\section{Introduction}

Studies on the concept of the 'smart city' have become an essential aspect of urban and environmental studies [1-4]. Whilst some believe that this is likely to be transient in terms of branding as a result of evolution [5], there is no unique definition for the smart city yet [3]. This might be related to 'smart' having a strong connotation to (technological, organizational, and social) innovation $[4,6,7]$.

Looking at cities that profile themselves as smart, one can conclude that not only do they contribute a variety of meanings to the smart city but also that they deploy vastly different approaches to becoming a smart city [7-13]. For instance, the comparative studies of Amsterdam, Ningbo, and Hamburg by Raven et al. (2019), and Glasgow, Bristol, Barcelona, and Bilbao by Calzada (2017) demonstrate how these smart cities vary in their institutional arrangements [14,15].

The present paper taps into these findings and seeks to systematically explore what different approaches are used to establish smart cities and reveals commonalities and differences in the patterns 
of coming into existence and the principles for design and governance that are used. Looking at the recent dominant approach from a perspective of social innovation $[7,16]$, we consider this necessary given the complexity of smart city planning and development. Meijer et al. (2018) even call smart city development a socio-technological system innovation process [4].

To reach the ambition level formulated above, we use a systematic, conceptual Input-Output model (IO model) [1] to shed light on different facets of smart city development, classifying them into the inputs, throughputs, and outputs. The main idea addressed in the present paper is to test key propositions from the IO model, in general, and more specifically, to systematically convey the design choices city planners and policy makers make in developing smart cities. In fact, the IO model does not propose a prescriptive procedure but rather the ideal type of a smart city development process as a framework for thinking about, making sense of, and finding ways to improve aspects in the implementation of smart city policies that are perceived as problematic.

In this paper, four smart city planning and development projects will be systematically studied and compared, i.e., Amsterdam, Barcelona, Dubai, and Masdar. Thus far, multiple studies have addressed these cases (also comparative studies), e.g., [10,14,15,17-33], but none of them focuses on design choices made, or reveals and classifies developmental pathways. The smart city planning and development projects we seek to analyse pertain to two different geographical regions in the world (Europe and the Middle East), where we expect that different institutions and different attitudes exist, each of them influencing the style of policy making and smart city planning. Other relevant factors pertain to differences in cultural background and political system [34].

Consequently, we seek to compare these smart city cases on the basis of the goals, policies, procedures, and resources used in their smart city development process. A comparison across cities seen from this angle has not been made yet in other studies. Whereas several studies were conducted to compare smart city practices (i.e., $[14,25,26,35])$, the innovation in this contribution is the focus on design choices made, and revealing and classifying developmental pathways. Therefore, the main research question in the present paper is: When comparing selected smart city projects, how can pathways for their implementation be classified?

The paper is structured as follows. The next section introduces a conceptual model in which smart city development is presented as an IO model, with key design variables of the smart city classified under inputs, throughputs, and output variables. Section 3 specifies the research design and methodology. Section 4 presents the four smart city cases. Section 5 provides the results of the comparative analysis of the four cases. Section 6 then discusses the results and presents a classification of smart city development pathways. Finally, in Section 7, the conclusions and recommendations for future research and policy makers are presented.

\section{Research Background}

\subsection{Design Choices for the Resources of Smart City Development}

An overview of different rankings for the smart cities around the world [36-39] that considers different criteria provides evidence for the existence of different approaches to smart city development. Whereas smart city development policy can be considered as a dominant approach in urban policy formulation, the challenging part of this dominant approach is in design and implementation. This section first introduces an IO model that pertains to resources, throughputs, and outcomes of a smart city development process [1] and then expands it to a framework for smart city design variables. In general, a conceptual model is a simplified external representation of a complex phenomenon that facilitates analysts in their understanding of it. Figure 1 provides a schematic overview of the IO model for smart city development that was constructed based on systems theory. General System Theory is aimed at developing a language in which the problems of many disciplines can be expressed and shared [40]. In this sense, system theory can be applied to many different fields and in many ways. Checkland and Haynes (1994) classified these varieties. Based on their classification we use 
systems theory for 'problem solving in a real-world situation'. This problem-solving category used as decision-making support is divided into 'hard' systems and 'soft' systems sub-varieties. Since our goal is to model a human activity system (smart city development process), it can be located within the realm of the (largely qualitative) soft systems approach. One could also claim that David Easton's famous portrayal of political systems (1957) was conceptual IO modeling ante datum [41].

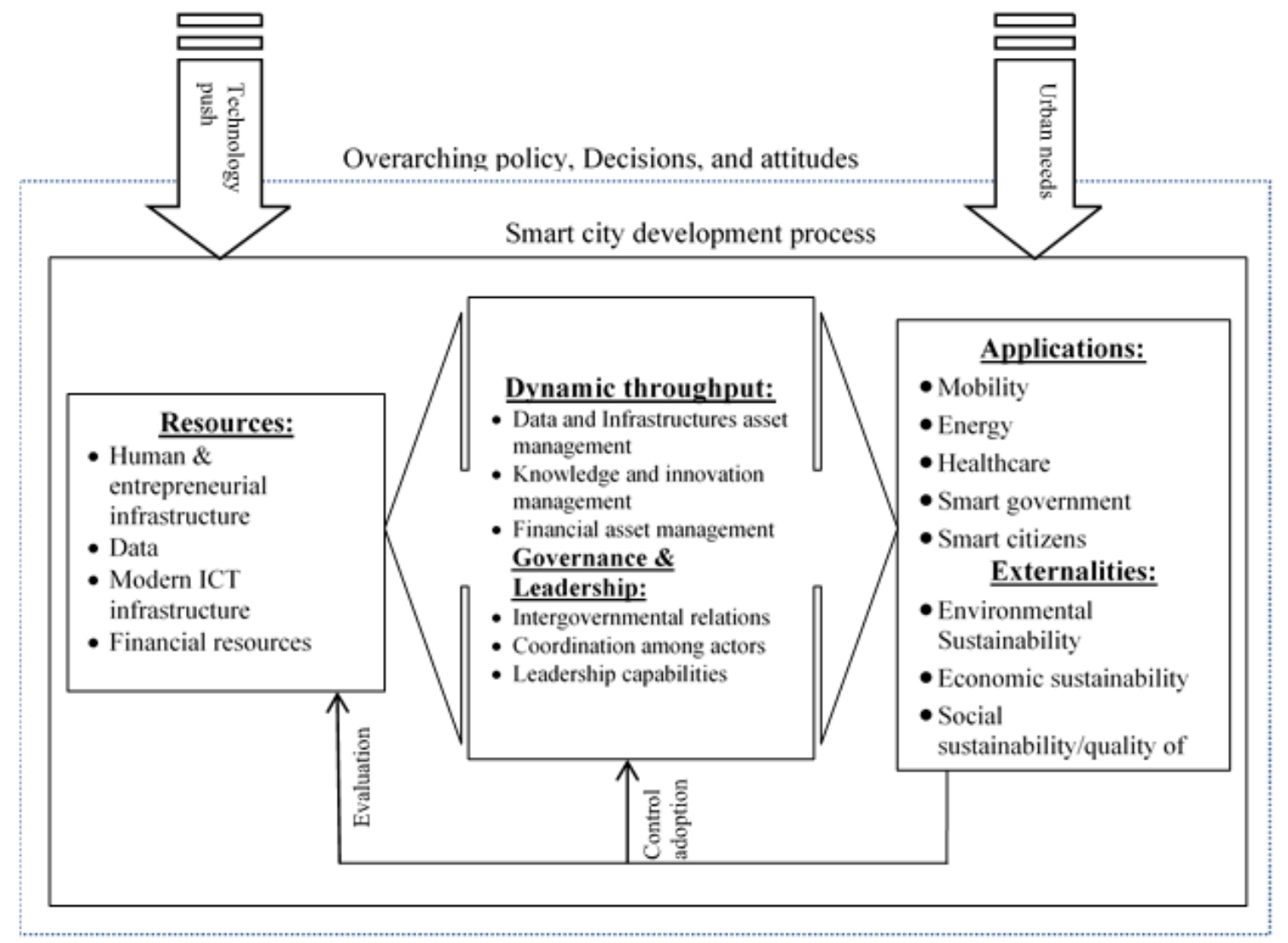

Figure 1. Input-Output (IO) model of the smart city development process [1].

The IO model for smart city development characterizes inputs (resources), throughputs, outputs (applications), and outcomes (externalities) of the smart city development process. The 'resources' pertain to human resources, knowledge and creativity, Information and Communication Technology (ICT) infrastructure, and financial assets. Throughputs are classified as the 'dynamic throughput', and the 'governance and leadership ability' to add value to the resources and turn them into the intended outputs [1]. The 'applications' associate with the outputs, whilst the 'externalities' refer to the outcomes coming as the intended consequences of the smartness that are the different domains of sustainability. There are still other IO models in existence for the analysis of smart cities, as, for instance, the one developed by Yigitcanlar (2018). His model stresses the interconnection between 'assets' as the inputs or resources of a city, 'drivers' as processes or opportunities for the smart city formation, and 'outcomes' as the results that transform a city into a smart city [2]. The special feature of our IO model is that it sheds light on those facets of the smart city development process where intervention becomes possible through design variables.

In optimization theory, design variables are defined as the entities that can change the shape or properties of the model within a specified set of choices [42,43]. An overview of relevant indicators for the design variables as they can be found in academic and grey literature was conducted. In order to specify the smart city design choices, first the determinant variables of each of these key facets need to be identified and defined. For human facet as design choices, Nam and Pardo (2011) highlight social learning, creativity, and education (which simply means becoming knowledgeable). Social learning 
concerns creativity for smart solutions and education to develop IT skills and knowledge-based human resources [44-46].

Another source of knowledge is data flows and information sharing [47,48]. Data assets are becoming increasingly important because of the emergence of the Internet of Things (IoT) [45]. The primary goal of the IoT is to connect to the 'things' to aggregate data [49], then to process data, and finally to analyse the aggregated data and provide services, applications, and information (for decision-making). The real-time analysis of city life can be used to model it, to predict and simulate urban processes, and/or to monitor, regulate and manage cities [50] for better delivery of utility services to citizens [50-52].

For a high-tech driven urban development, financial requirements have a pivotal role in determining roadmaps. Collaboration between the public and private sectors for investment in smart urban development projects is always supported as a desirable fiscal mechanism [53]. In practice, this collaboration is complicated due to different interests and attitudes stakeholders have vis-à-vis return on investment. Whereas private sector actors invest in urban commercial projects with a decent fiscal return, public sector actors focus on social improvements such as happiness, prosperity, and safety [54]. Public sector funding can be allocated by different governmental bodies, located in different levels of government, for instance, via municipal outlay, via national investment or supra-national budgets such as European (EU) funding (e.g., via EU framework programs like Horizon 2020, FP7, or Interreg) [55].

\subsection{Design Choices for the Throughputs}

Under the throughput category, three levels are discerned: leadership, governance, and management.

Government roles in smart city governance pertain to 'initiator' [56], 'facilitator' [57], 'regulator', or 'funder' [58]. Considering how the government interacts with other actors, there are different modes of governing smart cities, such as technocratic governance, citizen-centric governance, socio-technical governance, or hierarchical governance [59]. In order to determine governance structures, there is a need to specify the roles of the government, the decision-making process of formulating smart city policies, the actors who are involved, and means for engaging actors [12,51].

Knowledge and innovation management as a dynamic throughput refers to the ways of adding value to the city by tangible and intangible sources of knowledge [60,61]. Fostering and managing innovation towards propelling smart cities may involve establishing innovation centers and living labs, and 'champions' available to share promising innovative ideas.

Big data management aims to ensure the quality of data and transform data into knowledge [62] and to prevent the misuse of data. Issues like data theft, data ownership, data accessibility, and privacy issues call for proper management $[63,64]$.

Meijer and Bolivar (2016) argue that a smart city requires a focus on both economic gains and other public values. Financial management as a dynamic throughput is about increasing public and private fiscal viability to provide funding for smart city projects [54]. In terms of public funding, as Floater et al. (2014) argue, existing funding should be redirected away from inadequate and inefficient urban infrastructure development. In terms of private finance, the main issue is to provide a strong public-private alliance for raising private funds [54]. The former needs alignment of all the urban infrastructure development with smart city policies, whilst the latter requires a sound understanding of the complexity that goes along with public-private collaboration.

Leadership explicitly addresses the offices that lead the public administration of a smart city (e.g., mayor, ruler of the city, smart city office, city council, CTO (Chief Technology Officer of the city)). Leadership capabilities strongly depend on the leadership style of whoever is leading the smart city program. Switching to another type of leadership may change the shape or properties of the smart city. The ways leadership creates a vision, motivates and empowers people, collaborates with stakeholders and influences them are the indicators that determine leadership style [65]. 


\subsection{Design Choices for the Applications of Smart City Development}

The IO model presents the application domains for mobility, energy, health, governance, and citizens. Orlowskia and Romanowska (2019) developed an indicator to measure smart mobility. It contains four dimensions: (i) technical infrastructure, (ii) information infrastructure, (iii) mobility methods and vehicles used for this purpose, and (iv) legislation [66].

Walnuma et al. (2019) define 'smart energy' as the goal of achieving energy systems that are highly energy-efficient, increasingly powered by renewable and local energy sources enabled by new technologies, and less dependent on fossil fuels [67]. This vision of smart energy has spurred the development of new approaches to future sustainable energy systems such as smart grids, green buildings, smart meters, and solar photovoltaic panels [68,69].

Another domain to become smart in cities is healthcare. Here, 'smart healthcare' pertains to affordable and quality patient-centered health services enabled by healthcare technologies (e.g., ICT supported, smart sensors, devices, and systems) along with big data analytics [70].

Taking advantage of these smart applications and solutions requires citizens to share data [71]. From a participation perspective, it is one-way communication between citizens and the smart city. In need of innovation, smart cities strive to reach higher levels of citizen participation for sharing ideas [45]. Doody (2013) states that smart citizens need smart governance [72]. Smart governance then refers to the use data and ICT to produce effective, responsive, and transparent modes of governance [73]. Wilke (2007, p. 165) argues that smart governance needs the 'redesigning' of formal democratic governance structures. Main areas of smart governance pertain to smart administration, smart interaction with stakeholders, smart security and safety, and smart infrastructures [74].

\section{Research Design and Methodology}

In this research, we used a cross-case research design to which we applied the analytical framework (IO model) presented in the previous section. The cross-case comparison of the specific cases was made in four steps. First, applying systems theory (and more specifically, the soft system variety) in order to tackle the research problem (implementation of smart city development policy), we used the Input-throughput-Output model to map the facets and relevant purposeful activities that we named smart city design variables. Then we applied the design variables framework (Table 1) to the different cases as a tool to describe their design choices in the real world. The third step was to scale their design choices in order to verify their common and unique choices. The next step was to analyse the design choice. For this purpose, we adopted the qualitative techniques of pattern matching and explanation building to generate descriptive analyses of the cases [2]. In this regard, pattern matching refers to scanning for similarities, dissimilarities, and patterns pertaining to design variables that influence smart city development pathways. This helped us realize our main goal, which is to classify different smart city pathways and generate insight regarding promising policy actions and interventions.

Table 1 provides an overview of smart city design variables based on the IO model presented in Section 2 with available indicators for each of the facets mentioned. 
Table 1. The design variables and indicators of the smart city development process.

\begin{tabular}{|c|c|c|c|}
\hline & Smart City Attributes & Design Variables & Indicators (Presence of) \\
\hline \multirow{3}{*}{ Inputs } & HR and Entrepreneurship & $\begin{array}{l}\text { Educating and training people } \\
\text { Transferring (attracting) educated and skilled people } \\
\text { Nurturing the innovation environment } \\
\text { Attracting innovative companies }\end{array}$ & $\begin{array}{c}\text { Supporting and strengthening universities and research centers (HR1) } \\
\text { Launching knowledge transfer projects (e.g., scholarships, sabbaticals) (HR2) } \\
\text { Specific policy in place to promote innovation (HR3) } \\
\text { Supporting and encouraging programs for innovative companies (Science and technology parks, free zones) (HR4) }\end{array}$ \\
\hline & $\begin{array}{l}\text { Information and Communication } \\
\text { Technology (ICT) and Data }\end{array}$ & $\begin{array}{l}\text { Data aggregation } \\
\text { Data processing } \\
\text { Data real-time analysis }\end{array}$ & $\begin{array}{l}\text { Big data establishment (D1) } \\
\text { Data science centers (D2) } \\
\text { Data visualization (D3) }\end{array}$ \\
\hline & Financial resources & $\begin{array}{l}\text { Supra-national and national investment } \\
\text { Local government investment } \\
\text { Public-private investment } \\
\text { Foreign investment }\end{array}$ & $\begin{array}{l}\text { Supra-national and national smart city development policy and budget (F1) } \\
\text { Smart city profile and allocated budget (F2) } \\
\text { Collaboration with the private sector (F3) } \\
\text { International brand and investors }\end{array}$ \\
\hline \multirow{5}{*}{ Throughputs } & Governance & $\begin{array}{l}\text { Governance structures; technocratic, citizen-centric, } \\
\text { socio-technical, hierarchical, surveillance }\end{array}$ & $\begin{array}{l}\text { Role of the government and decision-making process (G1) } \\
\text { Actors are involved and engaged (G2) }\end{array}$ \\
\hline & Knowledge and Innovation management & $\begin{array}{l}\text { Open innovation } \\
\text { In-house R\&D }\end{array}$ & $\begin{array}{c}\text { Living Labs, idea-sharing champions (KI1) } \\
\text { Innovation Centers, Smart City R\&D department (KI2) }\end{array}$ \\
\hline & Data management & $\begin{array}{l}\text { Establishing a data authorization } \\
\text { Open/closed/ or shared data platform }\end{array}$ & $\begin{array}{c}\text { Data Laws (DM1) } \\
\text { Data accessibility (DM2) }\end{array}$ \\
\hline & Financial management & $\begin{array}{c}\text { Redirecting funds away from inadequate, inefficient urban } \\
\text { infrastructure development } \\
\text { Raising private funds }\end{array}$ & $\begin{array}{c}\text { Alignment of the urban master plan with smart city policies (FM1) } \\
\text { Having a collaboration platform (FM2) }\end{array}$ \\
\hline & Leadership & Leadership styles & $\begin{array}{l}\text { Vision creation and the bigger image (L1) } \\
\text { Motivating and empowering people (L2) } \\
\text { Collaborating with people and influencing them (L3) }\end{array}$ \\
\hline \multirow{5}{*}{ Outputs } & Smart Mobility & $\begin{array}{l}\text { Smart transportation infrastructures } \\
\text { Smart public transportation } \\
\text { Smart private transportation }\end{array}$ & $\begin{array}{l}\text { Smart (sensor and actuator equipped) roads and traffic lights, smart parking, bicycle routes (SM1) } \\
\text { Interconnected public transportation, smart vehicles, information application (SM2) } \\
\text { EVs (Electric Vehicles), autonomous driving, car-sharing (SM3) }\end{array}$ \\
\hline & Smart energy & $\begin{array}{l}\text { Renewable energy } \\
\text { Energy-efficient buildings } \\
\text { New technology for utilities }\end{array}$ & $\begin{array}{c}\text { Stationary energy use to be supplied from renewable energy sources (SE1) } \\
\text { Building regulations, energy certificates (SE2) } \\
\text { Smart grids, smart meters (SE3) }\end{array}$ \\
\hline & Smart health & $\begin{array}{c}\text { Smart health monitoring systems } \\
\text { Smart health management and information applications }\end{array}$ & $\begin{array}{l}\text { Remote health monitoring, mobile health monitoring, or wearable health monitoring (SH1) } \\
\text { Mobile applications for medication information, weight management, information regarding hospitals and clinics (SH2) }\end{array}$ \\
\hline & Smart citizens & $\begin{array}{l}\text { One-way communication } \\
\text { Two-way communication } \\
\text { Co-creating and co-designing }\end{array}$ & $\begin{array}{l}\text { A participation platform for data sharing (SC1) } \\
\text { A participation platform for idea sharing (SC2) } \\
\text { A participation platform for cooperative policies (SC3) }\end{array}$ \\
\hline & Smart governance & $\begin{array}{l}\text { Smart administration } \\
\text { Smart interaction } \\
\text { Smart security and safety } \\
\text { Smart policies }\end{array}$ & $\begin{array}{l}\text { Redesigning norms based on smart solutions (technologies) (SG1) } \\
\text { Participation and collaboration via social media and social networking (SG2) } \\
\text { Using smart devices and data analytics for surveillance (SG3) } \\
\text { Using big data analytics for decision-making (SG4) }\end{array}$ \\
\hline
\end{tabular}




\subsection{Case Selection}

The present study used a small-N comparative analysis research approach. Small-N case comparisons, also known as 'case-oriented comparative methods' (Ragin, 1987, pp. 34-52), are systematic comparative illustrations for insight-generating and in-depth studies of cases as a whole [75].

Four cases were compared: Amsterdam Smart City, Barcelona Smart City, Smart Dubai, and Masdar City. All four were well-known, did well on international rankings (e.g., the Global Smart City ranking issued by Juniper Research in 2016; the Smart City Index issued by Ernst and Young, in 2017; the global Smart City Discourse Network issued by Joss et al. in 2017) [35,36,76]. These four may not necessarily have been known as the four 'best practices' globally, but they were known for having very different governance styles and smart city discourses, and showing various types of smart city applications in place, and were therefore intriguing to compare. Joss et al. (2019) presented a list of 27 cities based on a systematic webometric investigation of the smart city global discourse network [35]. Their study showed that Barcelona and Amsterdam are seen as pioneers (third and fourth place after London and Singapore). These two cities are located in Europe, having democratically governed cities. In contrast, Dubai and Masdar City are located in the Middle East and are governed by sheikhs. Masdar City in Abu Dhabi and Dubai are well-branded smart cities in the world [29,77].

\subsection{Data Collection}

Data were collected between 2017 and 2019 by means of site visits and fieldwork in all four cases, participatory observation in smart city workshops and meetings, including the Barcelona Smart City World Congress 2018 and 2019 editions, and the Amsterdam Smart City Open House meetings in 2017 and 2019. Data collection also involved in-depth interviews with 32 stakeholders who were involved in smart city project development. Finally, much information was collected from official documents and websites.

\subsection{Data Analysis and Operationalization}

The cases were compared by descriptions of the current situations and their design choices, using the operationalized indicators (See Table 2). In order to derive a classification of smart city development pathways, we used a multi-method approach to identify patterns in the data that would provide more insight into the pathways, enable us to discern between them, and develop a classification. First, we analysed the case narratives for the four different cases and reflected on key events occurring that spurred smart policy development and implementation. Because this was a complex task with rich data available for each case, we decided to treat these mostly qualitative data in a way to make them apt for structured analysis. Toward that end, (qualitative) scores were assigned for each case using a four-point scale ranging from ' 0 ' for absence, ' + ' for having a plan without implementation, and ' ++ ' for a plan that has begun, to ' +++ ' for implementation completed because ordinal scales were used. For the throughput indicators, which used a nominal scale, we tried to label the design choices and then compare them. In addition, the cases were compared through the interpretation of the commonalities, differences, and the patterns these revealed.

Table 2. The input and output indicators.

\begin{tabular}{|c|c|c|c|c|}
\hline Indicators & Absence (0) & Plan Without Implementation (+) & Plan Has Begun (++) & Implementation Completed $(+++)$ \\
\hline \multicolumn{5}{|l|}{ HR1 } \\
\hline \multicolumn{5}{|l|}{ HR2 } \\
\hline \multicolumn{5}{|l|}{ HR3 } \\
\hline Etc. & & & & \\
\hline
\end{tabular}


This led us to measure the data and to create a data matrix that included these data for each city measured against all indicators as presented in Table 1. We used this table to analyse development more structurally, using two approaches. First, we conducted an explorative statistical analysis focusing on bivariate correlations, focusing foremost on assumed relations between input and output indicators (See Supplementary Material). This would inform us about potential covariation but would offer too little evidence to confirm any causal relationship. This led us to seek confirmation using the rich qualitative data of the four cases, break them down into items pertaining to input, throughput, and output of the cases, fill them out with qualitative information, and interpret and attach meaning to how the development pathways played out for each of the four cases (See Supplementary Material). This also included a comparison of commonalities and differences between the four cases. Based on triangulation between the three types of data analysis used-i.e., (i) interpretation of the four case narratives, (ii) statistical analysis, and (iii) qualitative comparative analysis of the qualitative comparative data matrix - we conceived development pathways for smart city project implementation of the four cases and created insights on key commonalities and differences between them. Having more information available on case study storylines, narratives, and information on input, throughput, and output, we were able to interpret and further understand the case studies at a higher level of abstraction, which made it possible to discern key values used by policy makers that support key decisions and the ways they play out in the development pathways used in the four cases. Finally, following the next step of interpretation of the four cases, we discerned fundamental values as drivers and classification of development pathways to emerge from the data.

\section{A Brief Description of the Cases}

We now present the four cases and show how each of them can be understood in terms of the concepts of the IO model. The origin of the smart city concept in the four cases is also explored.

\subsection{Masdar City}

In 2006, the Masdar City project was launched in order to develop the world's most sustainable eco-city with the vision of making Abu Dhabi a reference for knowledge and collaboration on the advancement of renewable energy, clean technologies, and sustainable development [21,29,78]. The mission of the project was not only to address the sustainability challenges of the United Arab Emirates (UAE) but also to develop commercially viable solutions in renewable energy and sustainable real estate. However, after more than ten years, the number of residents is around 1300 [79], whilst it was initially planned to house 40,000 permanent residents with an additional 50,000 commuting to work and study in Masdar City [77]. With the emergence of smart cities as a trendy competitive urban policy, it was transformed from an eco-centered project into a smart city project. The smart city project was then based on four pillars: (i) research and academics; (ii) sustainable real estate; (iii) clean energy deployment; and (iv) clean-tech innovation. Since Masdar City entails the construction of an entirely new city, it can be seen as a living lab for developing and testing new technologies to evaluate how they can integrate into the unified platform for developing a smart city [80].

\subsection{Amsterdam Smart City}

Two years later, in Amsterdam, the Amsterdam Smart City program set out with the primary goal of reducing $\mathrm{CO}_{2}$ emissions [59]. The program was started with the focus on smart energy and smart grids by the City of Amsterdam and Alliander through a three-year project funded by the EU [31]. When the project was finalized a discussion started on how the program could continue and stand on its own feet. This was followed by the Amsterdam Economic Board, which decided to take over the program as the coordinator and to govern and fund it, using a collaborative platform. The first driver for moving toward implementing a smart city policy was based on the results of climate change discussions [31]. More recently, the scope of the smart city was broadened to include areas that can improve the quality of life of citizens [30,81]. Amsterdam also developed a circular economy and 
sustainable structural vision that sketches an image of Amsterdam as a future-proof, innovative, data (evidence) driven, and collaborative city by 2040.

\subsection{Barcelona Digital (Smart) City}

In 2011, Barcelona also launched a smart city policy of its own aligned with the European Union's strategy to create a more sustainable, smart, and inclusive path for development. Following that, a national plan for smart cities was launched in Spain called the 'Digital Agenda for Spain', which allocated EUR 170 million for actions related to city objectives, 5G technology, interoperable virtual labs, smart tourism, public services platforms, and rural territory. Currently, Barcelona's approach to becoming a smart city derives from the digital city. Its profile pertains to 'Barcelona Digital City: the right to the (smart) city'. The Mayor of Barcelona Colau (2018) states, 'Our goal is to exploit digitization and achieve a city that is more open, fair, circular and democratic by putting technology at the service of people' [82]. In this sense, Barcelona's smart city foundation is based on digital transformation, digital innovation, and citizen empowerment.

\subsection{Smart Dubai}

For Dubai, the smart city journey developed from the concept of smart government. In 2014, an executive office for the Smart Dubai program was established to expand the concept to different areas based on the vision of the Ruler of Dubai [1,49]. The vision was to make Dubai the happiest city on the earth [83]. This is pursued by using smart technology innovation as one of the main tools contributing to creating happiness. Next to spurring technological innovation, a cornerstone of the approach of the Smart Dubai strategy pertains to having all city stakeholders on board [84].

\section{Results}

\subsection{Design Input Choices}

\subsubsection{Masdar}

To provide the human and entrepreneurship resource for the Masdar City development, Abu Dhabi's main funding project in research and education development is allocated to the Masdar Institute of Science and Technology (MIST), which is located within Masdar City. MIST, in collaboration with the Massachusetts Institute of Technology, aims to foster energy and sustainability innovations. In 2017, it merged with Khalifa University. When it comes to innovation policy, Abu Dhabi follows the national strategy for advanced innovation (2018), which targets the establishment of an innovation platform and led to initiation of the 'UAE Innovation Month' festival. In order to attract innovative companies, Abu Dhabi established a policy for developing several free zones at a large scale per unit around Masdar and provided companies with high-profile locations inside Masdar City [34,78]. In terms of data and ICT infrastructure assets, the Mubadala Company made substantial investments in building ICT infrastructures. Mubadala, which is a regional government investment company, is responsible for funding and provisioning infrastructure by either its institutions or outsourcing. It also founded Khazna Data Centers (in Masdar City and Meydan Dubai) to deliver a combined 18+ MegaWatt (MW) of IT load in 2012. Therefore, Masdar City is majority-owned by the Mubadala Investment Company, which belongs to the Abu Dhabi Government in collaboration with the International Renewable Energy Agency (IRENA). The Mubadala Company announced that $\$ 20$ million would be allocated to the Masdar project, but after spending a few million, the remaining budget was invested in other projects, mostly international projects.

\subsubsection{Amsterdam}

To make the potential human capital available for Amsterdam Smart City, the Smart City Academy and Amsterdam Institute for Advanced Metropolitan Solutions (AMS) were established 
as the knowledge-sharing programs for smart city development, aiming to support knowledge and build a human infrastructure. Amsterdam has a specific policy in place to promote innovation in coordination with national and European policies, such as Innovation Union, Horizon 2020, and the Digital Agenda (Policy framework: European Strategy for Amsterdam, 2019). To support start-ups and emerging tech companies, Amsterdam Science Park and the startup village inside it offer an ecosystem for innovation. Moreover, in 2015, the City of Amsterdam initiated a public-private action program called 'Startup Amsterdam'. It aims to assist startups and innovative companies so they can accelerate their growth sustainably [85]. Apart from the benefits of an established start-up hub, a talented workforce, and the spirit of innovation, Amsterdam offers skilled workers at start-ups and innovative companies a $30 \%$ personal income tax advantage [85].

Amsterdam has the second-largest Internet exchange point in the world and is considered the second top city in the world in terms of technology readiness [86]. As such, it benefits from modern technology infrastructures to make the city smarter. There is a single portal for the data in Amsterdam ('City Data') established by the City of Amsterdam in 2015. City Data uses big data collections and tries to share as much data as possible, which is open to anyone who wants to use the data. This includes the collected data from eight policy domains: traffic and infrastructure, tourism, geography, population, public space and green, urban development, welfare, and energy. At the time of writing this article, the portal was under development. In terms of making the financial resources available, Amsterdam Smart City initially used EU framework project funding (i.e., Horizon2020) [87]. Later on, Amsterdam Smart City (ASC) established a public-private partnership portal to provide a favourable platform for collecting co-funding from the private sector.

\subsubsection{Barcelona}

For human resource development in Barcelona Smart City, the Institute for Advanced Architecture of Catalonia (IAAC) is one of the main research centers in collaboration with the city council of Barcelona. One of its departments, the so-called 'Fab lab', is currently developing projects in smart devices for data collection among citizens in collaboration with the Smart City Expo and World Congress in Barcelona. Barcelona's innovation policy is mainly based on the real open innovation approach [18]. It prefers to have open innovation centers for anyone to contribute rather than doing mere researches inside the universities. That is why the city council's cooperation with research centers and universities is generally carried out through the research labs. The director of Barcelona's Smart City Program stressed that the strength of Barcelona's smart city strategy relies on its cyclic and cross-cutting innovation model [88]. Apart from fostering innovation in a collective collaborative way, the city council of Barcelona pays special attention to promoting entrepreneurship. This process is supported by Barcelona Activa, which is a local development agency belonging to the Barcelona City Council encouraging entrepreneurship and offering support to companies and startups.

The Barcelona City Council established the municipal data office for public data sovereignty. Currently, it is promoting three projects: CityOS, Open Data Bcn, and Monitoring Gentrification, to aggregate data from the various sensors distributed throughout the city and numerous sources. CityOS is an advanced data analysis platform that offers comprehensive and transversal connectivity to serve citizens and the city. The platform is based on the main idea of using data to enable the foresight and the ability to predict situations in order to make better decisions and reactions. It is an open-code IoT platform that everybody can download and develop or modify.

In both Amsterdam and Barcelona Smart City initiatives are linked to projects that use EU framework funding (i.e., Horizon 2020). Apart from that, Barcelona City Council is the responsible entity for the majority of funding. In terms of foreign investment, according to the Global Cities Investment Monitor 2019, Barcelona is the seventh most popular global destination attracting international investments [89]. 


\subsubsection{Dubai}

The most significant supporting programs for universities and research centers are focused on three districts: Dubai International Academic City (DIAC), Dubai Knowledge Village, and Dubai Internet City. DIAC lists middle-of-the-road colleges, schools, and universities from around the world [34] established by TECOM Group (a governmental entity) as a free zone dedicated to higher education and the pursuit of intellectual growth. Apart from Dubai's main higher education project in DIAC, major training programs to develop human resources target civil servants [90].

However, skilled and educated workers have always been welcomed to work in Dubai, and there is momentum in the Emirates to increase the number of highly skilled and educated local workforces' so-called 'Emiratization' [91]. According to the Ministry of Education's Strategic Plan for 2017-2021, Dubai's innovation policy was formulated to establish a culture of innovation in the institutional and working environment. To encourage start-ups and innovative companies to come, Dubai's government established a significant number of high-tech free zones and science parks. In parallel, the Smart Dubai startup initiative was launched, having three programs in place to support emerging technologies and entrepreneurs. These are: (i) the Global Blockchain Challenge; (ii) the Dubai Smart City Accelerator; and (iii) the Dubai Future Accelerators. In terms of ICT infrastructure assets, The Network Society Index indicates that Dubai is 26th in performance in sustainable urban development and ICT maturity.

For data assets as an essential resource for the smart city, Dubai Data Establishment is the governing body with authority to push this strategy whilst seeking to implement the roadmap for Dubai Data. In order to process and utilise data, 'Dubai Pulse' is the central platform that provides and computes, stores, and analyses services for the categorical use of various entities. Currently, Smart Dubai office serves the analytical data as a single mobile application, 'Dubai Now', which helps citizens to manage bills, track their visas, renew the trade licenses, register cars, plan journeys by public transportations, and monitor health.

In both Dubai and Abu Dhabi, the smart city program is considered to be part of the National Happiness policy [83]. Therefore, the Smart Dubai initiative is established and funded by the ruler of Dubai. However, enjoying a positive global image, Dubai has ample ability to attract foreign investment. An overview of how the four smart cities perform against smart city resources is presented in Table 3, which is constructed based on the scaling method defined in the data operationalization section (Table 2).

Table 3. Smart city development in Amsterdam, Barcelona, Dubai, and Masdar.

\begin{tabular}{|c|c|c|c|c|}
\hline Design Choices/Cases & Amsterdam & Barcelona & Dubai & Masdar \\
\hline Educating and training people & +++ & +++ & ++ & + \\
\hline Transferring (attracting) educated and skilled people & +++ & +++ & ++ & + \\
\hline Nurturing the innovation environment & +++ & +++ & + & + \\
\hline Attracting innovative companies & +++ & +++ & +++ & ++ \\
\hline Data aggregation & ++ & ++ & +++ & +++ \\
\hline Data processing & ++ & ++ & ++ & ++ \\
\hline Data real-time analysis & + & ++ & ++ & ++ \\
\hline Supra-national and national investment & +++ & +++ & ++ & ++ \\
\hline Local government investment & ++ & ++ & +++ & +++ \\
\hline Public-private investment & +++ & ++ & ++ & ++ \\
\hline Foreign investment & ++ & +++ & +++ & + \\
\hline
\end{tabular}

\subsection{Design Throughput Choices}

\subsubsection{Masdar}

The governance structure of Masdar is mainly based on a holistic approach to developing renewable energy and sustainability by creating a value chain from research to investment. Dubai and Masdar City share common governance features, such as the monarchical rule and central authority, 
that make their decision-making process fast and flexible; the idea is initiated by the rulers, policies are formulated and then adopted by citizens with high levels of trust. However, Abu Dhabi, having abundant financial wealth because of its oil and gas resources, is much stronger than Dubai. With a global approach, Masdar City launched the 'sustainability week' as a platform for accelerating the world's sustainable development. It brings together policy makers, industry specialists, technology pioneers, and the young generation of citizens for sharing knowledge, implementing strategies, and delivering solutions for the world's sustainable development. In terms of the smart city in-house R\&D, Masdar recently established the Honeywell Masdar Innovation Center of cutting-edge solutions for smart applications.

\subsubsection{Amsterdam}

Situated in a totally different political and government system from the Emirates, in the case of Amsterdam the ASC platform is an innovative platform for connecting ideas and challenges between municipalities, partners, and companies to accelerate doing/learning in order to strengthen smart solutions, market development, business models and replication [30,92]. In 2011, the municipality of Amsterdam governed ASC with more than 70 public and private partners [31]. Within the ASC platform, the city administration has different roles apart from being the initiator, to a facilitator and from financer to customer [93]. At present, the dominant approach to managing innovation within the smart city is to develop and test smart urban solutions in a real-life context (urban living labs) [59]. For ASC, the living labs are mapped in the middle of the stakeholder's collaboration (Figure 2).

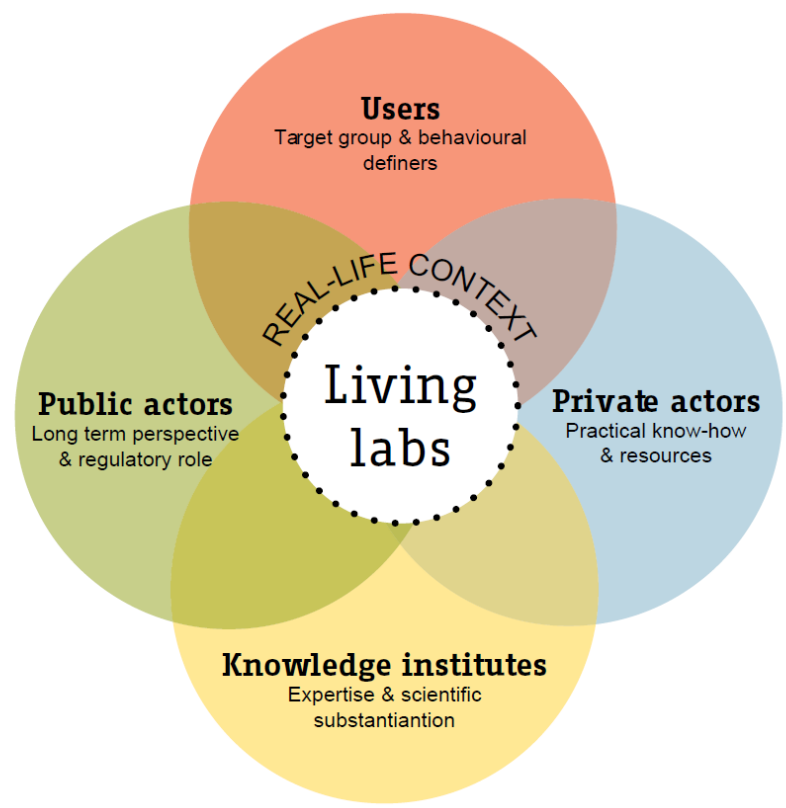

Figure 2. Overview of the stakeholders involved in the Amsterdam Smart City (ASC) living lab [94].

The Amsterdam Institute for Advanced Metropolitan Solutions (AMS) is responsible for ASC living labs working on six different themes: i.e., circularity, food, resilience, energy, mobility, and data. In addition, ASC uses open-house programs and open meet-ups for communicating and empowering citizens. Within the smart city context, knowledge and innovation management is closely connected to data management driving innovative solutions. For data-related decision-making, the IO model focuses on two crucial aspects: data laws and data accessibility. Amsterdam and Barcelona are part of the European Union's DECODE project aiming to return data sovereignty to the citizens. Currently, four DECODE pilots are running in Amsterdam and Barcelona to test the technology and approach. Amsterdam City Data is openly accessible through the Internet, and data that are public can be freely used by anyone. However, some of the data are available for authorized city employees only. 


\subsubsection{Barcelona}

To govern Barcelona Smart City, following the formulated smart policy in 2011, Barcelona City Council launched the project 'Barcelona Smart City Strategy, Planning and Implementation' in collaboration with DOXA. DOXA is a consulting company that assisted and coordinated Barcelona's Smart City strategy by supporting planning, execution, and monitoring actions. In 2015, the project outcomes pertained to the smart strategy development and implementation, the definition of a governance model (See Figure 3), storytelling and communication framework [88]. The main governmental entities of Barcelona Smart City are the City Council, the Barcelona Provincial Council, and Area Metropolitana de Barcelona (AMB).

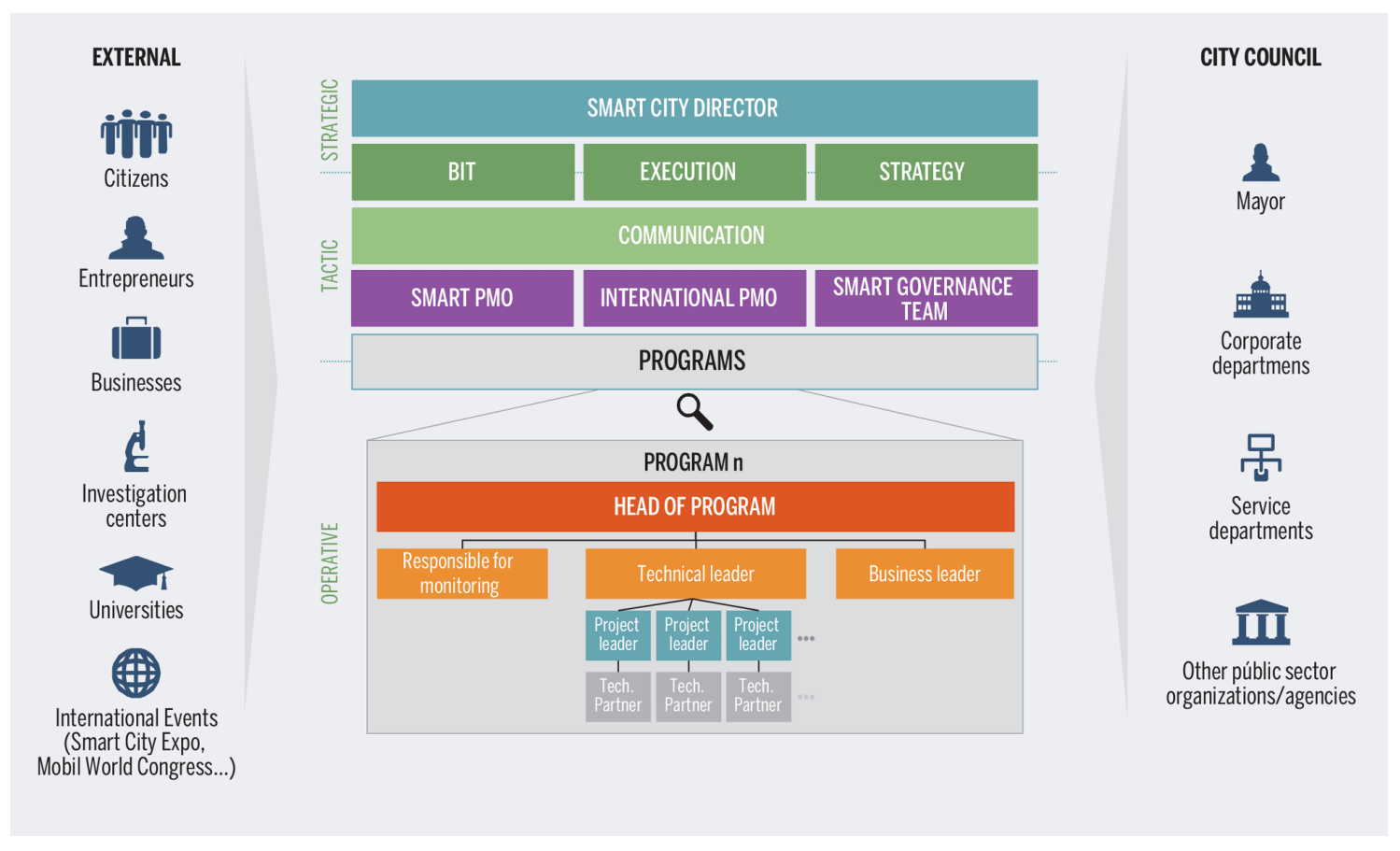

Figure 3. The Barcelona Smart City governance model [88].

One of the key points of Barcelona Smart City programs at the early stage was the development of a community of citizens and developers, and installations for Small to Medium Enterprises' (SMEs) experimentation with the Living Labs. Barcelona's 22@ innovation district was initiated by the City Council in need of an urban renovation strategy for the transformation of the industrial area to the knowledge economy area [59]. It brings universities, research centers, start-ups, and emerging tech companies together to create synergies and foster innovation. The whole district operates as an urban lab that offers opportunities for technology companies to move to the district, run pilot programs, and test new technologies [95]. There is a European Union (EU) General Data Protection Regulation (GDPR) for European city authorities in digital ethics and rights concerning citizens' empowerment [96]. Barcelona's Digital Plan 2017-2020 is the main agenda for data policies and strategies aligned with GDPR $[96,97]$. According to Calzada (2018), the three strategic initiatives regarding data protection and regulation are: 'Data Commons Barcelona', 'City Data Analytics Office', and 'Decode' (the EU's scientific) project [96]. Data Commons Barcelona offers an open-source policy toolkit regarding ethical digital standards 'for cities to develop digital policies that put citizens at the center and make governments more open, transparent, and collaborative' [98]. The city council of Barcelona also presented 'Decidim Barcelona', a participatory democracy (digital) platform for communicating and empowering citizens. Barcelona Municipal data office is currently working on the Open Data Bcn project to develop a platform for sharing the information generated or stored by public bodies with individuals and organizations. 


\subsubsection{Dubai}

The Smart Dubai governance structure is based mainly on visionary leadership and a positive approach to developing happiness. Setting up a 'champion' in line with the overarching policy of developing the smart city is Dubai's unique pathway to engage citizens for coordinating, strategizing, and implementing programs and projects. Smart Dubai points to the happiness champion as an essential component of Dubai's smart city transformation where all the partners can work in close collaboration with the Smart Dubai Office (Smart Dubai, 2019). Dubai is also developing its first Artificial Intelligence (AI) Lab in partnership with IBM to support Dubai's AI roadmap. The AI Lab's first strategy is to transform citizen engagement by infusing AI into services and operations, and disrupting business processes [99]. In terms of the smart city in-house R\&D, Dubai already has several innovation centers. Dubai has a set of comprehensive documents on data authorization, including Dubai data law, Dubai data policy, Dubai data manual, and the Dubai data model, which are all accessible online.

Last but not least, as a dynamic throughput, leadership style plays an important role in the Emirati cases, where the initiators of the smart city programs are the rulers of Dubai and Abu Dhabi. In European cases, the initiators are institutions affiliated with either municipality or city council. So the way of motivating and empowering citizens in Dubai and Masdar is based on getting inspiration from the vision of leader, whilst in Amsterdam and Barcelona smart cities are based mainly on two-way communication.

\subsection{Applications and Externalities}

All efforts to mobilize and manage resources are to provide solutions and then transform them into smart applications. A common classification many studies agree on pertains to five clusters, i.e., those of mobility, energy, health, governance, and citizen contributions to the different aspects of sustainability (externalities) $[6,100,101]$.

\subsubsection{Masdar}

Smart transportation policies in Masdar City are based on the elimination of car use. They deploy cutting-edge technology solutions like the personal rapid transport (PRT) system. This pertains to a driverless automated transport system that can carry four passengers. Although it is mentioned on the official website of Masdar City that the system was implemented, in practice, it only turns around the building for a few minutes and it is clearly not as well-developed or functional as marketed through its branding media.

Deploying clean energy worldwide is Masdar City's core objective to make Abu Dhabi a hub for sustainability and renewable energy. Green building prototypes (Masdar Eco-villa), Solar PV Plant, and the Wind Tower are launched projects in Masdar City.

In early 2017, Masdar City and Huawei signed an agreement to use Huawei's IoT platform to develop applications for increased health, productivity, and sustainability. The ultimate goal is to empower Masdar City residents in making better health decisions. Citizen participation seems not to be at the core of the Masdar City concept; in Masdar official documents and on the website (Masdar corporate brochure), the words 'citizens', 'residents', and 'people' are mentioned only once to address Abu Dhabi Sustainability Week. The Abu Dhabi Sustainability Week is a knowledge platform for the global sustainability community and the largest sustainability gathering in the Middle East to discuss viable and effective strategies to mitigate climate change.

Since automation through the cutting-edge technologies is the main facet of Masdar City, there is a unified service desk called 'one-stop shop' where people and companies can access a wide variety of government and business services, including registration and licensing, visa and medical checks, ID card processing, document authentication, and so on. It refers to the key facet of Masdar's social attitude as 'customer satisfaction' [78]. 


\subsubsection{Amsterdam}

Amsterdam has been at the forefront of smart mobility for many years [81]. What makes ASC different is that smart solutions and strategies are not only based on modern technologies but also help to develop simple solutions that are supported by cultural capacities. Amsterdam as 'the world capital of cycling' developed smart mobility solutions through smart bicycling, along with the electric car [102] and car sharing in terms of private transportation [103]. ASC also provides a network platform for public transport, which is easily accessible to visitors and residents via smartphone applications.

One of the crucial partners of ASC is the Chief Technology Officer (CTO), who has many initiatives on innovative mobility. ASC also uses the smart traffic management system to optimize the traffic flow and works on a project (Amsterdam Practical Trail), creating a future where cars, navigation systems, traffic lights, and information signs are connected and working on an automated basis. The urban energy transition was the starting point and primary goal of the ASC program [30]. City-Zen is an international consortium project on urban energy transition in Grenoble and Amsterdam to integrate new energy solutions in existing buildings and systems. A Virtual Power Plant (for storage and trade of surplus wind or solar-PV energy), Smart grid, The District Heating and Comfort Cooling network, Smart cooling, and Retrofitting homes are part of City-Zen project. 'Healthcare has less attention in our smart program so far, we just started to have strategic partners to develop the smart healthcare theme,' states Ger Baron, the chief technology officer of Amsterdam.

The main product that the ASC team developed is an online platform for people to share their projects and initiatives and look for collaboration. Collaboration with citizens is a clear goal of Amsterdam Smart City to keep the city livable, but currently it is more focused on collaboration with businesses and entrepreneurs [17]. Amsterdam Smart Citizens Lab is a bottom-up way to explore smart solutions from citizen-driven innovations as well as to help citizens to become aware of smart lifestyles and ecosystems whilst it has early adopter citizens receptive to new technologies and sustainable solutions [93]. Considering the smart governance domain, administrative affairs in Amsterdam, like registration, payment lay-out, and taxes, are mostly paper-based. Amsterdam, however, is one of the first cities that has a Chief Technology Officer (CTO) in its governance body contributing to e-health, circular economy, and mobility themes of ASC.

\subsubsection{Barcelona}

Barcelona's smart mobility policy began with raising public awareness through a research and innovation project ('Mobility Urban Value') aiming to encourage behavioral change in mobility by using new technologies. Connected mobility, safe and smart mobility for pedestrians and cyclists, clean, affordable, and efficient public transport, and integrating electric vehicles (EVs) into the transport system are the main aspects of Barcelona smart mobility that calls itself 'the right to smart mobility'.

Barcelona Energia's (the public electricity distributor) energy transition model incorporates smart energy with the mission of producing a 100\% certified renewable energy supply plan that began in July 2016 and is supported by the City Council with a budget of EUR 130 million (Barcelona Self-sufficient Energy Plan 2014-2024). For this purpose, Barcelona adopted encouraging plans like subsidies for the installation of photovoltaic panels and thermal solar panels, energy renovation, and energy improvements. Barcelona Energia (2018) also reported that 87 solar energy installations are already distributed around the city and the Programme for Promoting Solar-Energy Generation has been established, which includes 73 projects for installing more solar energy panels on rooftops, party walls, facades, and pergolas [104].

In the same way as ASC, Barcelona seeks two-way communication and co-creation of solutions and policies with citizens. For that purpose, there are several so-called democratic Barcelona projects. One of them is 'Decidim Barcelona', which aims to provide a portal for participation processes. The 'Smart City Week' program is also an initiative to bring citizens closer to the notion of Barcelona Smart City, which is 'a city that uses its accumulated knowledge and technologies to achieve a more sustainable, fair, and inclusive urban setting' [105]. 
As a collaborative governance platform, the 'City Protocol' project is another common project between Amsterdam and Barcelona that offers an 'Internet of Cities' platform to communicate, share solutions across diverse cities, and learn from each other.

\subsubsection{Dubai}

In Dubai, due to the Emirati preference for luxury and private transportation, smart mobility projects are mostly related to smart lights, smart parking, traffic control management, and increasing the share of electric vehicles (a smart initiative by Dubai Electricity and Water Authority) on the roads [24]. Since the UAE is always interested in using the title of 'the first', the Abu Dhabi-Dubai hyperloop is the world's first commercial hyperloop set to open in 2020 for the Expo 2020 [34].

Shams Dubai is the main smart energy initiative by Dubai Electricity and Water Authority (DEWA), which is the key partner of Smart Dubai in this field. Shams is focused on expanding the solar panel installations on buildings to generate electricity and connect them to DEWA's grid. The program was started on governmental buildings and aims to expand among household and private building owners [106]. The Green Building Regulations establishment is another major plan for energy efficiency launched by Dubai Supreme Council of Energy and DEWA for all new buildings to ensure the efficient use of electricity, water, and renewable energy [24].

In contrast to Amsterdam, Dubai pays a lot of attention to the health domain of its smart program. Dubai Health Authority's (DHA) smart applications are available to use for different purposes such as Patient Services (for medications, appointments, and lab results), Dammi (for blood donation), Salem (for medical fitness and occupational health screening), and Sheryan (for health licensing).

Smart Dubai tries to interact with citizens through different mobile applications. If the energy domain is the primary goal of smart city development in Amsterdam, for Dubai it began in the governance domain [22]. Paperless government policy is the goal for Dubai's smart administration.

Table 4 presents an overview of how the four smart city cases perform against smart city output indicators.

Table 4. Applications of smart city development in Amsterdam, Barcelona, Dubai and Masdar.

\begin{tabular}{ccccc}
\hline Design Choices/Cases & Amsterdam & Barcelona & Dubai & Masdar \\
\hline Smart transportation infrastructures & +++ & +++ & ++ & + \\
Smart public transportation & +++ & +++ & + & + \\
Smart private transportation & +++ & ++ & ++ & + \\
Renewable energy & ++ & ++ & + & + \\
Building energy efficiency & ++ & ++ & +++ & ++ \\
New technologies for utilities & + & ++ & + & ++ \\
Smart health monitoring systems & + & + & ++ & 0 \\
Smart health management and information applications & + & + & ++ & + \\
One-way communication & ++ & ++ & ++ & + \\
Two-way communication & +++ & ++ & + & + \\
Co-creating and co-designing & ++ & ++ & + & 0 \\
Smart administration & 0 & ++ & ++ & ++ \\
Smart interaction & ++ & +++ & +++ & +++ \\
Smart security and safety & $\mathrm{n} / \mathrm{a}$ & $\mathrm{n} / \mathrm{a}$ & $\mathrm{n} / \mathrm{a}$ & $\mathrm{n} / \mathrm{a}$ \\
Smart policies & ++ & ++ & ++ & + \\
\hline
\end{tabular}

Even though one obvious case of using big data collected from the environment is for surveillance objectives, in principle, governments do not publish information on this issue.

\section{Towards a Classification of Smart City Development Pathways}

In Sections 4 and 5 the results from the data collection and observations revealed the design choices for inputs, throughputs, and outputs. This led to several important analyses associated with smart city development paths. The observed data for input and output indicators are shown in Tables 4 and 5 . 
Subsequently, the qualitative and quantitative analyses of the observed data of the cases, through using pattern matching and explanation building techniques, led us to formulate their fundamental values as drivers for smart city development. The results are presented in Table 5.

Table 5. Smart city development pathways (Amsterdam, Barcelona, Dubai, and Masdar).

\begin{tabular}{|c|c|c|c|}
\hline Case & Main Driver (Core Element) & Development Path & Key Features \\
\hline Amsterdam & Innovation & $\begin{array}{l}\text { Innocratic (Startup and } \\
\text { business-driven) }\end{array}$ & Competition, entrepreneurial Innovative, Bottom-up approach \\
\hline Barcelona & Inclusion & Sociocratic (Participation-driven) & $\begin{array}{l}\text { Democracy, Citizen empowerment through technology and } \\
\text { citizens' data sovereignty Participatory, Co-creation }\end{array}$ \\
\hline Dubai & Visionary-ambitious leadership & $\begin{array}{l}\text { Aristocratic (State and } \\
\text { service-driven) }\end{array}$ & $\begin{array}{l}\text { Being first, being best, Top-down Happiness, government } \\
\text { services, branding }\end{array}$ \\
\hline Masdar & Technological optimism & $\begin{array}{l}\text { Technocratic (Investment and } \\
\text { branding-driven) }\end{array}$ & Visibility, lighthouse projects, branding \\
\hline
\end{tabular}

Significant results of the statistical analysis were found between 'nurturing of the innovation environment' and certain application domains such as smart transportation infrastructure, renewable energies, or smart mobility. Nurturing the innovation environment was also found to relate positively to investment from higher tiers of government (like Barcelona and Amsterdam getting EU-funded projects). In addition, nurturing the environment positively related to ways of bottom-up participatory innovation and decision-making, i.e., 'two-way communication', 'co-creation', and 'co-designing'. This, in turn, also showed a positive statistical relationship to indicators of the smart citizen domain. Other significant correlations were found between 'two-way communication' (of citizens and government) and 'educating and training of staff'. The 'data aggregation' and 'data processing' design variables turned out to be related in particular to the application domain of smart health, but also connected with 'smart private transportation' and 'building energy efficiency'. The analysis showed that there were remarkable interactions between 'smart policies', 'data processing', and 'one-way communication' (which points to sharing data from citizens).

These results in combination with the qualitative data analysis table (See Supplementary Material), enabled us to identify the pathways (See Table 5). The main drivers and the key values that were revealed from the process analysis (of smart city development) informed us about the pathways smart city development has taken in the four cases of the present study.

Looking at the origins of the smart city program in each case showed that environmental issues, and eventually, the idea of making a city 'sustainable and future proof', formed the main motivations to start undertaking actions that would result in smart city development plans, policies, and actions. However, the environmental issue alone did not suffice, as it was local leadership taking ownership of the latter to issue a vision and take the first steps in smart city development, goal setting, and policy. The visionary scenario of Amsterdam was structured around sustainability [107]. The ultimate goal of Amsterdam Smart City to increase the quality of life was making it a future-proof city based on a circular economy. This implied a city for the future, ready to respond to all kinds of disruptions and changes whilst remaining attractive and competitive in innovation, which is the core element of the process. Mora (2017) believes that the key to the success of Amsterdam Smart City is 'strategic planning' that is based on three main rules: strategic thinking, collaboration, and inclusion [31]. In Masdar City, improving the quality of life was interpreted as taking advantage of the technologies of the day to provide environmental quality and better services to citizens $[29,108]$. But taking advantage of technology with only the focus on technology sounds like technological optimism [109]. It was high-risk gamble for Masdar, with a lot of confidence in technology and little space for the social aspect, that led Cugurullo (2013, p. 35) to end his study on the case of Masdar with the statement of 'We leave Masdar City hoping that Abu Dhabi's example will not cross the desert' [78]. For Dubai, a smart city is the happiest city and that guarantees the quality of life, based on the vision and ambition of the Ruler of Dubai. This vision sounds utopian due to the difficulty of defining happiness and the variety of opinions people have of it. Another challenge for Dubai is that more than $80 \%$ of its population consists of migrant laborers [34], for whom different criteria apply when compared with locals. Nonetheless, 
putting a lot of effort into the smart healthcare domain by Smart Dubai can be seen as a human-centric approach (especially in times of the COVID-19 pandemic) that ensures a higher quality of life for its citizens. Barcelona Smart City is a digital (smart) city with technological sovereignty of citizens that puts technology at the service of people, as Calzada $(2018$, p. 6) states: 'Barcelona is currently explicitly branding itself as an inclusive, democratic, and participative smart city'. Barcelona is a leading smart city in terms of digital ethics and citizen data sovereignty; however, the challenge ahead remains for citizens to become aware of their digital rights and duties [96]. Its experimental pathway in this regard can provide an answer to the question 'is the open-data era, and citizen data ownership realistic or will remain as a dream?'.

In sum, the results show that governance structures are a main determinant for successfully developing a smart city. It involves local government, other (higher level) governments, private organizations, knowledge institutes, business enterprises, and citizens, and requires integrating technology (as the main enabler) with creativity (for entrepreneurship) and viable business models (the financial-economic driver). This leads to the emergence of smart applications (smart government, smart citizens, smart mobility, energy and healthcare) and sustainability. In all cases, it also requires outside investment to start smart city initiatives and projects, not only from the private sector but also from higher levels of government such as the EU or national government. Once having secured a financial basis the first projects are set up to nurture the innovation environment and address how citizens can benefit or even participate in bottom-up smart city development (except for the case of Masdar City). After the initial projects are set up, initiatives are taken to develop platforms that are embedded in local policies and supported by local political and administrative leadership, sometimes taking novel forms like in the Amsterdam Smart City case.

In parallel, action is taken to set up living labs and data-driven experiments in order to learn from e-innovations in practical, urban environments. Surrounding these labs is involvement of stakeholders from different sectors like industry, knowledge institutes, government, and citizens. Local and state governments also use them as vehicles to attract more business investment. To support these innovation zones, other-often low taxation-measures are implemented by public authorities. Finally, in all of the cases local authorities-but in particular Masdar and Dubai-strive to have lighthouse projects in places they can show at international events [29], like Expo Dubai 2020 or Barcelona hosting the Smart City World Congress 2019, or brand themselves with, in order to attract future investment and prolong their development paths of smart city development.

Nonetheless, Amsterdam, Barcelona, Masdar, and Dubai still have quite different approaches to developing and governing a smart city. Amsterdam and Barcelona are more focused on horizontal co-ordination with ample room for bottom-up decision-making, using participatory platforms [59]. In contrast, Dubai and Masdar use more vertically oriented, respectively aristocratic and technocratic government approaches $[13,29]$. How cases play out in terms of these dimensions and in which category they eventually end up in the matrix determines in the end how the development pathways take shape and differ from the more general pathway described earlier in this section. Describing and analysing how they develop and can be discerned will be addressed in future research.

\section{Conclusions}

This paper examined different approaches to smart city development that reflect different ways in which cities are governed, and different pathways urban governments take to become smart. The present study aimed to further understand how urban governments formulate and use policies by systematically analysing and comparing four smart city projects. The main research question was: When comparing a selection of smart city projects, how can pathways for their implementation be classified? By using a comparative case study research design the present study mapped how different design choices of smart cities play out in their implementation and governance. The four cases were: Smart Dubai, Masdar City, Barcelona Smart City, and Amsterdam Smart City. We selected two Emirati/Arab and two EU cases (one in the North and the other in the South of Europe) to increase 
the variation in geographic location, culture, type of city, and government, polity, public leadership style, and institutions. To systematically analyse the four cases the Input-Output model for smart city development [1] was used and elaborated, containing indicators that are indicative for design choices and developmental pathways that influence their development.

The results of our study show that smart city development in Amsterdam is based on a business-driven approach, which puts innovation at its core; Masdar's choices reflect technological optimism; social inclusion is the focus of the Barcelona Smart City pathway; and visionary-ambitious leadership is the main driver behind Smart Dubai. This variety makes their smart city development pathways different. Comparing smart city development in the four cities reveals that they also have commonalities. In all cases, smart city development took off in response to grand environmental challenges and the need to make the city future-proof. In addition, leadership is needed to adopt this vision and to start the process of initial policy making and planning. Next, in order to support capacity development, outside investment is needed, which concerns collecting a budget not only through private sector investment but also from higher levels of government. Once project budgets are secured, the first activities are embarked on to nurture the innovation environment and address how citizens can benefit from or even participate in bottom-up smart city development. In parallel, initiatives are taken to develop platforms embedded in local policies and supported by local political and administrative leadership. Finally, local authorities strive to develop lighthouse projects that allow them to brand themselves in order to attract future investment and extend their developmental pathways for smart city development. Although Amsterdam, Barcelona, Masdar, and Dubai were compared analytically one should not forget that they are located in contexts that vary a great deal.

Limitations to the present study pertain to the case selection, which included only European and Arab countries, and excluded other ones, like pioneering smart cities in North America and East Asia. Because of this bias in the case selection, it is conceivable that potentially more pathways exist in other cities around the world. However, this may be taken up in future research. In addition, there is a concern regarding the linearity of the IO model, which will be taken up in our future research as well by introducing a new version of the IO model through a neural network modeling approach that will shed light on the interconnections between different facets of the smart city development process.

The present study offers insights that can inform future research agendas on smart city development. First, we suggest that future studies on different smart city cases in other parts of the world (for instance, China and the United States of America) can provide further detail in the use of the smart city design choices framework and discover more pathways. Investigating various smart city cases with contextual differences-most importantly, cultural and political system variations-can reveal new aspects of development pathways and their relative success and failure. Moreover, we would like to draw the attention of future researchers to a current evolution of smart city concepts and pathways from the technology-driven approach towards an emerging one of 'inclusive smart cities'. Taking this shift into account can provide more insight into forecasting and backcasting [110] as the next steps in smart city development. The analysis of design choices made in the four cases also provides guidance for future research on how to transfer lessons from developmental-pathway-supporting policies among various smart city initiatives.

Finally, the concept and findings presented in this study for policy makers provide practical clues as well as policy lessons on how to develop a smart city. Most of the time, confusion and contradictions appear when a comprehensive team that includes urban policy makers and planners, government officials, economists, environmental engineers, technology companies, and sometimes even citizens starts working on a smart city development program. They have different expectations, which makes establishing a common language for smart city development a challenge. For cities that have just gotten started with smart city development programs, this is in fact the first challenge they face. With the broader question in mind of how best to govern one's smart city development, an urban manager may look at a variety of examples, their practices, and outcomes. Learning from the experiences of leading cities is a common way to formulate and implement urban policies through drawing positive and 
negative lessons. We expect this trend to continue in the future and hope to have contributed our share to improving that practice.

Supplementary Materials: The following are available online at http://www.mdpi.com/2071-1050/12/10/4030/s1.

Author Contributions: N.N. conceived of the idea of the research and is the main author. M.d.J. and T.H. supervised all stages of this research work and provided guidance. The paper structure was prepared by all authors. Data collection was conducted by N.N. and analysed by N.N and T.H. All authors contributed significantly to this work by reading and editing it and agree to the published version of the manuscript.

Funding: This research was primarily funded by the Erasmus Initiative for the Dynamics of Inclusive Prosperity.

Acknowledgments: The authors are indebted to Cornelia Dinca, Ger Baron, Leendert Verhoef, Jordi Cirera, Frans Sengers, and Ali al-Azzawi for their support in the data collection. They are also grateful to Simon Joss and Robert van Gasteren for comments on an earlier version of this paper.

Conflicts of Interest: The authors declare no conflict of interest.

\section{References}

1. Input-Output Modelling for Smart City Development. J. Urban Technol 2020, Author Omitted for Review in press.

2. Yigitcanlar, T.; Kamruzzaman, M.; Foth, M.; Sabatini-Marques, J.; da Costa, E.; Ioppolo, G. Can cities become smart without being sustainable? A systematic review of the literature. Sustain. Cities Soc. 2018, 45, 348-365. [CrossRef]

3. Caprotti, F. Spaces of visibility in the smart city: Flagship urban spaces and the smart urban imaginary. Urban Stud. 2019, 56, 2465-2479. [CrossRef]

4. Meijer, A.; Thaens, M. Urban Technological Innovation: Developing and Testing a Sociotechnical Framework for Studying Smart City Projects. Urban Aff. Rev. 2018, 54, 363-387. [CrossRef]

5. Cowley, R.; Caprotti, F. Smart city as anti-planning in the UK. Environ. Plan. D Soc. Sp. 2019, 37, 428-448. [CrossRef]

6. Anthopoulos, L.; Janssen, M.; Weerakkody, V. Comparing smart cities with different modeling approaches. In Proceedings of the 24th International Conference on World Wide Web, Florence, Italy, 18-22 May 2015; pp. 525-528. [CrossRef]

7. Giffinger, R.; Lu, H. The Smart City Perspective A Necessary Change from Technical to Urban Innovation; Fondazione Giangiacomo Feltrinelli: Milan, Italy, 2015.

8. Li, X.; Fong, P.S.W.; Dai, S.; Li, Y. Towards sustainable smart cities: An empirical comparative assessment and development pattern optimization in China. J. Clean. Prod. 2019, 215, 730-743. [CrossRef]

9. De Falco, S. Are smart cities global cities? A European perspective. Eur. Plan. Stud. 2019, 27, 759-783. [CrossRef]

10. Tok, E.; McSparren, J.J.; Merekhi, M.A.; Elghaish, H.; Ali, F.M. Crafting smart cities in the gulf region: A comparison of masdar and lusail. In Handbook of Research on Digital Media and Creative Technologies; IGI Global: Hershey PA, USA, 2015.

11. Lee, J.H.; Hancock, M.G.; Hu, M.C. Towards an effective framework for building smart cities: Lessons from Seoul and San Francisco. Technol. Forecast. Soc. Chang. 2014, 89, 80-99. [CrossRef]

12. Dameri, R.P.; Benevolo, C. Governing Smart Cities: An Empirical Analysis. Soc. Sci. Comput. Rev. 2016, 34, 693-707. [CrossRef]

13. Angelidou, M. The Role of Smart City Characteristics in the Plans of Fifteen Cities. J. Urban Technol. 2017, 24, 3-28. [CrossRef]

14. Raven, R.; Sengers, F.; Spaeth, P.; Xie, L.; Cheshmehzangi, A.; de Jong, M. Urban experimentation and institutional arrangements. Eur. Plan. Stud. 2019, 27, 258-281. [CrossRef]

15. Calzada, I. The Techno-Politics of Data and Smart Devolution in City-Regions: Comparing Glasgow, Bristol, Barcelona, and Bilbao. Systems 2017, 5, 18. [CrossRef]

16. Calzada, I.; Cobo, C. Unplugging: Deconstructing the smart city. J. Urban Technol. 2015, 22, 23-43. [CrossRef]

17. Capra, C.F. The Smart City and its Citizens. Int. J. E Plan. Res. 2016, 5, 20-38. [CrossRef] 
18. Gascó, M.; Trivellato, B.; Cavenago, D. How Do Southern European Cities Foster Innovation? Lessons from the Experience of the Smart City Approaches of Barcelona and Milan. In Smarter as the New Urban Agenda. Public Administration and Information Technology; Gil-Garcia, J., Pardo, T., Nam, T., Eds.; Springer: Cham, Switzerland, 2016; Volume 11, pp. 191-206.

19. Confer, V.; Madeira, T. Barcelona as a Smart City Lessons Learned from the Evolution of the Concept and the Influence in the City Attractiveness, VIII Conferência Anualdo Turismo Madeira. 2014. Available online: https://docplayer.net/1494769-Barcelona-as-a-smart-city-lessons-learned-from-the-evolution-of-theconcept-and-the-influence-in-the-city-attractiveness.html (accessed on 13 May 2020).

20. Mora, L.; Deakin, M.; Reid, A. Strategic principles for smart city development: A multiple case study analysis of European best practices. Technol. Forecast. Soc. Chang. 2019, 142, 70-97. [CrossRef]

21. Griffiths, S.; Sovacool, B.K. Rethinking the future low-carbon city: Carbon neutrality, green design, and sustainability tensions in the making of Masdar City. Energy Res. Soc. Sci. 2020, 62. [CrossRef]

22. Badran, A. Smart-Governments for Smart Cities: The Case of Dubai Smart-Government. In Smart Cities in the Gulf; Springer: Singapore, 2019; pp. 59-82.

23. Breslow, H. The smart city and the containment of informality: The case of Dubai. Urban Stud. 2020. [CrossRef]

24. Virtudes, A.; Abbara, A.; Sá, J. Dubai: A Pioneer Smart City in the Arabian Territory. IOP Conf. Ser. Mater. Sci. Eng. 2017, 245, 052071. [CrossRef]

25. Caprotti, F.; Cowley, R. Varieties of smart urbanism in the UK: Discursive logics, the state and local urban context. Trans. Inst. Br. Geogr. 2019, 44, 587-601. [CrossRef]

26. Cowley, R.; Joss, S.; Dayot, Y. The smart city and its publics: Insights from across six UK cities. Urban Res. Pract. 2018, 11, 53-77. [CrossRef]

27. Niederer, S.; Priester, R. Smart Citizens: Exploring the Tools of the Urban Bottom-Up Movement. Comput. Support. Coop. Work CSCW An Int. J. 2016, 25, 137-152. [CrossRef]

28. Mancebo, F. Smart city strategies: Time to involve people. Comparing Amsterdam, Barcelona and Paris. J. Urbanism. 2019. [CrossRef]

29. Yigitcanlar, T.; Han, H.; Kamruzzaman, M.; Ioppolo, G.; Sabatini-Marques, J. The making of smart cities: Are Songdo, Masdar, Amsterdam, San Francisco and Brisbane the best we could build? Land Use Policy 2019, 88, 104-187. [CrossRef]

30. Baron, G.; Brinkman, J.; Wenzler, I. Supporting sustainability through smart infrastructures: The case for the city of Amsterdam. Int. J. Crit. Infrastruct. 2012, 8, 169. [CrossRef]

31. Mora, L. How to Become a Smart City: Learning from Amsterdam. In Smart and Sustainable Planning for Cities and Regions; Bisello, A., Vettorato, D., Laconte, P., Costa, S., Eds.; Springer: Cham, Switzerland, 2017; pp. 251-266.

32. Angelidou, M. Four European Smart City Strategies. Int. J. Soc. Sci. Stud. 2016, 4, 18. [CrossRef]

33. Van Winden, W.; van den Buuse, D. Smart City Pilot Projects: Exploring the Dimensions and Conditions of Scaling Up. J. Urban Technol. 2017, 24, 51-72. [CrossRef]

34. De Jong, M.; Hoppe, T.; Noori, N. City Branding, Sustainable Urban Development and the Rentier State. How Do Qatar, Abu Dhabi and Dubai Present Themselves in the Age of Post Oil and GlobalWarming? Energies 2019, 12. [CrossRef]

35. Joss, S.; Sengers, F.; Schraven, D.; Caprotti, F.; Dayot, Y. The Smart City as Global Discourse: Storylines and Critical Junctures across 27 Cities. J. Urban Technol. 2019, 26, 3-34. [CrossRef]

36. Juniper Research, Smart Cities-What's in it for Citizens? 2017. Available online: https://newsroom.intel.com/ wp-content/uploads/sites/11/2018/03/smart-cities-whats-in-it-for-citizens.pdf (accessed on 13 May 2020).

37. Eden Strategy Institute, Top 5 Smart City Governments Rankings 2018/9. 2018. Available online: https: //www.smartcitygovt.com/ (accessed on 24 February 2020).

38. Berrone, P.; Ricart, J.E.; Carrasco, C.; Duch, A. IESE Cities in Motion Index 2018, IESE, ST-471-E. 2018. Available online: https://www.ieseinsight.com/fichaMaterial.aspx?pk=148539\&idi=2\&origen=3 (accessed on 13 May 2020).

39. Bay, O. Singapore Beats Dubai and London to Top Spot in Smart City Rankings. ABI Research. 2018. Available online: https://www.abiresearch.com (accessed on 24 February 2020).

40. Checkland, P.; Haynes, M.G. Varieties of systems thinking: The case of soft systems methodology. Manag. Control Theory 1994, 3, 151-159. [CrossRef] 
41. Easton, D. Systems theory in political science. World Polit. 1957, 9, 383-400. [CrossRef]

42. Terlaky, T.; Curtis, F.E. Modeling and Optimization: Theory and Applications-Selected Contributions from the MOPTA 2010 Conference; Springer Nature: Basel, Switzerland, 2012; Volume 21. [CrossRef]

43. Arora, J.S. Optimum Design Problem Formulation. Introd. Optim. Des. 2004, 15-54. [CrossRef]

44. Nam, T.; Pardo, T.A. Conceptualizing smart city with dimensions of technology, people, and institutions. In Proceedings of the 12th Annual International Digital Government Research Conference: Digital Government Innovation in Challenging Times, College Park, MD, USA, 12-15 June 2011; pp. 282-291. [CrossRef]

45. Appio, F.P.; Lima, M.; Paroutis, S. Understanding Smart Cities: Innovation ecosystems, technological advancements, and societal challenges. Technol. Forecast. Soc. Chang. 2018, 142, 1-14. [CrossRef]

46. Borri, D.; Camarda, D.; Grassini, L. Learning and sharing technology in informal contexts: A multiagent-based supporting approach. In Proceedings of the 2011 IEEE 12th International Conference on Mobile Data Management, Lulea, Sweden, 6-9 June 2011; Volume 2, pp. 98-105. [CrossRef]

47. Negre, E.; Rosenthal-Sabroux, C.; Gasco, M. A knowledge-based conceptual vision of the smart city. In Proceedings of the Annual Hawaii International Conference on System Sciences, Kauai, HI, USA, 5-8 January 2015; pp. 2317-2325. [CrossRef]

48. Gil-Garcia, J.R.; Pardo, T.A.; De Tuya, M. Information Sharing as a Dimension of Smartness: Understanding Benefits and Challenges in Two Megacities. Urban Aff. Rev. 2019. [CrossRef]

49. Abbate, T.; Cesaroni, F.; Cinici, M.C.; Villari, M. Business models for developing smart cities. A fuzzy set qualitative comparative analysis of an IoT platform. Technol. Forecast. Soc. Chang. 2018, 142, 183-193. [CrossRef]

50. Kitchin, R. The real-time city? Big data and smart urbanism. GeoJournal 2014, 79, 1-14. [CrossRef]

51. Meijer, A.; Bolívar, M.P.R. Governing the smart city: A review of the literature on smart urban governance. Int. Rev. Adm. Sci. 2016, 82, 392-408. [CrossRef]

52. Fistola, R.; La Rocca, R.A. Smart City Planning: A Systemic Approach. In Proceedings of the 6th Knowledge Cities World Summit, Istanbul, Turkey, 9-13 September 2013; pp. 520-530.

53. Pattberg, P.; Widerberg, O. Transnational Multi-Stakeholder Partnerships for Sustainable Development: Building Blocks for Success. SSRN Electron. J. 2018. [CrossRef]

54. Huston, S.; Rahimzad, R.; Parsa, A. 'Smart' sustainable urban regeneration: Institutions, quality and financial innovation. Cities 2015, 48, 66-75. [CrossRef]

55. Engelbert, J.; van Zoonen, L.; Hirzalla, F. Excluding citizens from the European smart city: The discourse practices of pursuing and granting smartness. Technol. Forecast. Soc. Chang. 2019, 142, 347-353. [CrossRef]

56. Alkandari, A.; Alnasheet, M.; Alshekhly, I.F.T. Smart Cities Survey. In Proceedings of the IEEE 20th International Conference on High Performance Computing and Communications; IEEE 16th International Conference on Smart City; IEEE 4th International Conference on Data Science and Systems (HPCC/SmartCity/DSS), Exeter, UK, 28-30 June 2018; Volume 2, pp. 1726-1730. [CrossRef]

57. Winters, J.V. Why are smart cities growing? Who moves and who stays. J. Reg. Sci. 2011, 51, $253-270$. [CrossRef]

58. Gil-Garcia, J.R.; Pardo, T.A.; Nam, T. What makes a city smart? Identifying core components and proposing an integrative and comprehensive conceptualization. Inf. Polity 2015, 20, 61-87. [CrossRef]

59. Zygiaris, S. Smart City Reference Model: Assisting Planners to Conceptualize the Building of Smart City Innovation Ecosystems. J. Knowl. Econ. 2013, 4, 217-231. [CrossRef]

60. Polanyi, M. Sense-Giving and Sense-Reading. Philosophy 1967, 42, 301-325. [CrossRef]

61. Fernandez-Anez, V.; Fernández-Güell, J.M.; Giffinger, R. Smart City implementation and discourses: An integrated conceptual model. The case of Vienna. Cities 2017, 78, 4-16. [CrossRef]

62. Watts, S.; Shankaranarayanan, G.; Even, A. Data quality assessment in context: A cognitive perspective. Decis. Support Syst. 2009, 48, 202-211. [CrossRef]

63. Dijkers, M.P. A beginner's guide to data stewardship and data sharing. Spinal Cord 2019, 57, 169-182. [CrossRef]

64. Chierici, R.; Mazzucchelli, A.; Garcia-Perez, A.; Vrontis, D. Transforming big data into knowledge: The role of knowledge management practice. Manag. Decis. 2019, 57, 1902-1922. [CrossRef]

65. Samosudova, N.V. Modern leadership and management methods for development organizations. MATEC Web Conf. 2017, 106, 08062. [CrossRef] 
66. Orlowski, A.; Romanowska, P. Smart Cities Concept: Smart Mobility Indicator. Cybern. Syst. 2019, 50, 118-131. [CrossRef]

67. Walnum, H.T.; Hauge, Å.L.; Lindberg, K.B.; Mysen, M.; Nielsen, B.F.; Sørnes, K. Developing a scenario calculator for smart energy communities in Norway: Identifying gaps between vision and practice. Sustain. Cities Soc. 2019, 46, 101418. [CrossRef]

68. Lund, H.; Østergaard, P.A.; Connolly, D.; Mathiesen, B.V. Smart energy and smart energy systems. Energy 2017, 137, 556-565. [CrossRef]

69. Koutitas, G. The smart grid: Anchor of the Smart City. In Smart Cities; Springer: Cham, Switzerland, 2018; pp. 53-74.

70. Hossain, M.S.; Muhammad, G.; Alamri, A. Smart healthcare monitoring: A voice pathology detection paradigm for smart cities. Multimed. Syst. 2017, 25, 565-575. [CrossRef]

71. Bayar, D.Y. Smart Citizens: Smart cities from a different point of view. In Proceedings of the Inspire Conference.

72. Doody, L. Smart citizens need smart government. In Smart Citizens; Hemet, D., Townsend, A., Eds.; FutureEverything: Manchester, UK, 2013; pp. 55-58.

73. Goldsmith, S.; Crawford, S. The responsive city: Engaging communities through data-smart governance. Public Adm. Rev. 2014, 208. [CrossRef]

74. Scholl, H.J.; Scholl, M.C. Smart Governance: A Roadmap for Research and Practice. In iConference 2014 Proceedings; iSchools: Berlin, Germany, 2014. [CrossRef]

75. Lor, P.J. International and Comparative Librarianship Concepts and Methods for Global Studies. Rev. Educ. Res. 2019, 37, 57. [CrossRef]

76. Rapporto Smart City Index; Ernst \& Young Global Limited: Rome, Italy, 2016.

77. Abdulla, H. Behind the Scenes at Masdar City. 2019. Available online: https://www.arabianbusiness.com/ (accessed on 20 March 2020).

78. Cugurullo, F. How to Build a Sandcastle: An Analysis of the Genesis and Development of Masdar City. J. Urban Technol. 2013, 20, 23-37. [CrossRef]

79. McArdle, M. Is Masdar City a Ghost Town or a Green Lab? 2018. Available online: https://www.popsci.com/ masdar-city-ghost-town-or-green-lab (accessed on 20 February 2020).

80. Solomon, E. Masdar Institute and Huawei Partner to Leverage the Internet-of- Things for Development of 'Smart City' Applications. 2017. Available online: https://www.ku.ac.ae/ (accessed on 4 January 2019).

81. Vermast, F.A. Frans Anton Vermast: Amsterdam has been at the Forefront of Smart Mobility for Many Years. 2019. Available online: https://www.themayor.eu/en/frans-anton-vermast-amsterdam-has-been-atthe-forefront-of-smart-mobility-for-many-years (accessed on 20 April 2019).

82. Colau, A. Barcelona Smart City Visions; Ajuntament de Barcelona: Barcelona, Spain, 2018.

83. Al-Azzawi, A. Dubai Happiness Agenda: Engineering the Happiest City on Earth. In Smart Cities in the Gulf; Springer: Singapore, 2019; pp. 195-221.

84. Smart Dubai Officie, Our Vision Is to Make Dubai The Happiest City on Earth. 2018. Available online: https://www.smartdubai.ae/ (accessed on 21 February 2020).

85. I amsterdam, About StartupAmsterdam. 2019. Available online: https://www.iamsterdam.com/ (accessed on 21 February 2020).

86. Amsterdam a City of Opportunity; PWC: Amsterdam, The Netherlands, 2014; p. 48.

87. Söderström, O.; Paasche, T.; Klauser, F. Smart cities as corporate storytelling. City 2014, 18, $307-320$. [CrossRef]

88. Ferrer, J.R. Barcelona's Smart City vision: An opportunity for transformation. J. Field Actions 2017, 16, 70-75.

89. KPMG, G.P. Global Cities Investment Monitor. 2013, p. 28. Available online: https://gp-investment-agency. com/wp-content/uploads/2019/06/GlobalCitiesInvestmentMonitor2019web-compressed.pdf (accessed on 20 April 2019).

90. Smart Dubai Officie, Government Resource Planning Portal. 2019. Available online: https://grpportal.dubai. gov.ae/ (accessed on 15 December 2019).

91. UAE vision 2021. Ministry of Cabinet Affairs and the Future. 2014. Available online: http://fgccc.org/wpcontent/uploads/2016/08/UAE_Vision_2021.pdf (accessed on 13 May 2020). 
92. Dameri, R.P. Comparing Smart and Digital City: Initiatives and Strategies in Amsterdam and Genoa. Are They Digital and/or Smart? In Smart City; Dameri, R.P., Rosenthal-Sabroux, C., Eds.; Springer: Cham, Switzerland, 2014.

93. Van Winden, M.; Oskam, W.; van den Buuse, I.; Schrama, D.; va Dijck, W.; Frederiks, E.J. Organising Smart City Projects Lessons from Amsterdam: Lessons for Amsterdam; Hogeschool van Amsterdam: Amsterdam, The Netherlands, 2016; Volume 37, p. 118. [CrossRef]

94. Steen, K.; Van Bueren, E. Urban Living Labs: A Living Lab Way of Working, 4th ed.; Amsterdam Institute for Advanced Metropolitan Solutions: Amsterdam, The Netherlands, 2017.

95. De Barcelona, A. 22@Barcelona, The Innovation District; Ayuntament de Barcelona: Barcelona, Spain, 2012.

96. Calzada, I. (Smart) citizens from data providers to decision-makers? The case study of Barcelona. Sustainability 2018, 10, 3252. [CrossRef]

97. Ajuntament de Barcelona. City Data Commons. Available online: www.barcelona.cat (accessed on 17 April 2020).

98. Ajuntament de Barcelona. Ethical Digital Standards: A Policy ToolKit. Available online: www.barcelona.cat (accessed on 17 April 2020).

99. Lootah, W.; Miailhe, N. Dubai's Artificial Intelligence Roadmap. J. Field Actions 2017, 17, 44-46.

100. Neirotti, P.; De Marco, A.; Cagliano, A.C.; Mangano, G.; Scorrano, F. Current trends in smart city initiatives: Some stylised facts. Cities 2014, 38, 25-36. [CrossRef]

101. Chourabi, H.; Nam, T.; Walker, S.; Gil-Garcia, J.R.; Mellouli, S.; Nahon, K.; Pardo, T.A.; Scholl, H.J. Understanding smart cities: An integrative framework. In Proceedings of the 2012 45th Hawaii International Conference on System Sciences, Maui, HI, USA, 4-7 January 2012; pp. 2289-2297. [CrossRef]

102. Wagner, S.; Brandt, T.; Neumann, D. Smart city planning-Developing an urban charging infrastructure for electric vehicles. In Proceedings of the 22nd European Conference on Information Systems (ECIS), Tel Aviv, Israel, 9-11 June 2014.

103. Sengers, F. Smart-Eco Cities in the Netherlands: Trends and City Profiles. 2016. Available online: http: //www.smart-eco-cities.org/wp-content/uploads/2016/03/Smart-eco-Cities-Netherlands-2016.pdf (accessed on 15 May 2019).

104. De Barcelona, A. More Solar Energy for a Sustainable and Self-Sufficient City. 2018. Available online: https://ajuntament.barcelona.cat/ (accessed on 22 February 2020).

105. De Barcelona, A. Smart City Week. 2019. Available online: www.barcelona.cat (accessed on 24 April 2020).

106. Dubai Electricity and Water Authority. DEWA Announces 222 Buildings with Photovoltaic Installations as Part of Shams Dubai. 2016. Available online: https://www.dewa.gov.ae/ (accessed on 22 February 2020).

107. Gemeente Amsterdam. Plan Amsterdam \#5: De stad duurzaam; Gemeente Amsterdam: Amsterdam, The Netherlands, 2016.

108. Masdar Mubadala Company, the Masder Report on Technologies for Future Smart City Transit. 2018. Available online: https://masdar.ae/-/media/corporate/downloads/about-us/masdar-annualsustainabilityeports/masdar_report_on_technologies_for_future_smart_city_transit.pdf?la=en\&hash= 52CAA6DF141DA067E174F91976DC6F4B7DE9F578 (accessed on 13 May 2020).

109. Pontin, J. Technology and Optimism: Why Technologists are So Confident. 2009. Available online: https: //www.technologyreview.com/2009/02/24/215197/technology-and-optimism/ (accessed on 18 January 2020).

110. Vergragt, P.J.; Quist, J. Backcasting for sustainability: Introduction to the special issue. Technol. Forecast. Soc. Chang. 2011, 78, 747-755. [CrossRef]

(C) 2020 by the authors. Licensee MDPI, Basel, Switzerland. This article is an open access article distributed under the terms and conditions of the Creative Commons Attribution (CC BY) license (http://creativecommons.org/licenses/by/4.0/). 